\title{
THE LOGICO-SEMANTIC RELATION OF STUDENTS' PRESENTATION IN ACCELERATION PROGRAM OF SMA LABSCHOOL JAKARTA
}

\author{
Siti Drivoka Sulistyaningrum*, Yumna Rasyid ${ }^{* *}$ \\ Universitas Negeri Jakarta, The Faculty of Language and Arts, English Department ${ }^{*}$ \\ Language Teaching/Applied Linguistics Study Program of Graduate Program of \\ Universitas Negeri Jakarta, Indonesia** \\ vokase@yahoo.co.id* \\ yumzai.rasyid@gmail.com**
}

\begin{abstract}
This study aims at investigating the kinds of taxis and logico-semantic relation of students' presentation in Acceleration Program of SMA Labschool Jakarta. The meanings represented in clause complexes are analyzed based on the concept of relationship between clauses suggested by Halliday (1994: 373). The analysis of taxis and logico-semantic relation is necessary in order to present a pattern of the complexity of the acceleration students. The observation video was recorded in class K-12 then transcribed and analyzed by means of analysis of clause complexes proposed by Gerot and Wignell (1994: 21). The finding in the study shows that the clause complexity in the acceleration students' presentation is varied. In the first group consisting 4 female students, almost all kinds of taxis and logico-semantic are relation found in their presentation, except hypotactic extension. In correspondence with the first group, the second group consisting 4 male students, has produced all kinds of relation except locution. From all groups the type of taxis and logico-semantic relation mostly arises is paratactic elaboration. The analysis of meaning reveals that the dominant meaning is addition which appears from extension.
\end{abstract}

Keywords: logico semantic, students's presentation, acceleration program.

In expressing ideas through spoken or written language, people produce clauses as the representation of their ideas. Those clauses are combined to produce meanings which can be understood by others. The clauses which are logically connected is termed as 'clause complex'. Halliday (1994: 373) states two basic systems which rule the relation of the clauses; taxis and logico-semantic relation. The theory is supported by Gerot and Wignell (1994: 21) in which they also divide taxis into parataxis and hypotaxis, and state that the logico-semantic relation can be expansion (elaboration, extension and enhancement) and projection (locution and idea).

Rukmini (2010) analyzed the logico-semantic relation of clauses complexes in the abstracts of the final project reports produced by the English Department Students of Semarang State University. She found that the clause complexes made in the abstracts are of both parataxis and hypotaxis relation. The logico-semantic relations used are elaboration, extension, enhancement and idea, while the locution projection is not found at all. The realization of them is relatively good but some errors such as voice, grammar, tenses are still made by the students. Another research conducted by Udom Srinon and Peter White also deals with clause complexity. They conduct study about clause complex analysis on Thai university students' English essays in a longitudinal genre based course. In the study, they 
compared the development of students' writing ability in text they produce before and after joining the course. The results show positive trend of developments in the use of semantic relations in the latter students' text in which they included rich conjunctive relations and lexical resources in their later texts compared to the pretest texts.

The gap in this study, the theory will be used to analyze a way of expressing ideas in form of oral presentation. Oral presentation is one of the various classroom speaking activities which is commonly used in teaching and learning language context. It is a kind of prepared talk, where students make a presentation of a specific topic. Such talk is different from usual conversation since it is prepared and made based on the concerned study of the topic done by the students (Harmer, 2008).

Through language used in presentation, students express their ideas. And to give a good presentation, they are required to have sufficient knowledge of what to say and how to organize the language. Mastering what to say or the topic being presented will enable the students to know the flow of ideas, while mastering how to organize the language will ease them to convey the ideas clearly to the audience.

Frequently, in a presentation students make use of slides which consist of points that represent the ideas they need to inform. Those points then will be elaborated through their oral presentation. In their presentation, students will produce clause complexes. Thus, to examine how the students develop their ideas presented in slides through their utterances, the logico-semantic relation analysis will be functional. Gerot and Wignell (1994, p. 162) also stated that in spoken language the content tended to be spread out over a number of clauses with complex logicosemantic relations among them.

Relevance to the background, the writer is aiming at investigating how the students of K-12 of Acceleration Program in SMA Labschool Jakarta develop their ideas through clause complexes they produce by means of taxis and logico-semantic relation system.

This study is considered significant to enrich the study in the field of functional grammar, particularly in a clause complex analysis, in which this research focusing on the theory of taxis, logico-semantic relation, and logical meanings as well. The result gained from the study is to give information of how complex the language produced by acceleration students. This may be beneficial as a reflection of both teachers and students of acceleration program. Finally, it can be useful for those who want to conduct related studies.

\section{Logical Meaning}

Logical meaning is a part of ideational meanings which functions to relate units of experience (Saragih, 2008). "The logical meaning is devoted to the clause complex. Thus, logical function occurs in a clause complex.” (Saragih, 2008, p. 45). Halliday (2004, p. 373) maps out two basic systems that determine how one clause is related to another; they are: (i) the degree of interdependency, or taxis; (ii) the logico-semantic relation.

Halliday (2004, p. 373) defines taxis technically as degree of interdependency; and the two different degrees of interdependency as parataxis (equal status) and hypotaxis (unequal status). Hypotaxis is the relation between a dependent element and its dominant, the element on which it is dependent. Contrasting with this is 
parataxis, which is the relation between two like elements of equal status, one initiating and the other continuing.

Saragih (2008, p. 45) simplifies the definition by stating that parataxis is a clause that has an independent status which means that clauses can stand individually. "Thus, a paratactic relation is one in which the clauses as in a clause complex can stand individually. In traditional terminology such a relation is commonly known as coordinating relation.” (Saragih, 2008).

Halliday (2004, p. 375) also states that any pair of clauses linked by interdependency, or taxis is called as a clause nexus. The choice between parataxis and hypotaxis characterizes each relation in clause nexus within a clause complex; and clause complexes are often formed out of a mixture of parataxis and hypotaxis, as in the clause complex (Halliday, 2004).

The clauses linked as parataxis have the same status, therefore they are symbolized in numerical in the analysis, such as 1,2,3, 4 .... etc.; for example:

Cisil can sing very nicely and she also plays a guitar very well.

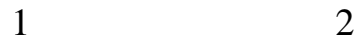

The clause 'Cisil can sing very nicely and she also plays a guitar very well' have the same status, they are both independent. In the other hand, in a relation of hypotaxis, one clause can stand by itself whereas the other has to be dependent on the dominant clause (Saragih, 2008). In the analysis, the dominant is usually coded $\alpha$ and the rests $\beta, \gamma, \delta$ etc., for example:

When the result is positive; people usually support the policy.

$\beta$

$\alpha$

Since the clauses 'people usually support the policy' is dominant compared to the clause 'when the result is positive', $\alpha$ is coded to it and the other $\beta$. Below are the examples of taxis in text taken from Introduction to Functional Grammar book (Halliday, 2004, p. 376).

Table 1. The example of taxis in text

\begin{tabular}{lll}
\hline 1 & & In pain, Kukul pulled out the arrow \\
\hline 2 & $\alpha$ & and headed for the river \\
\hline & $\beta$ & to wash his wound \\
\hline
\end{tabular}

The first relation is parataxis in 'In pain, Kukul pulled out the arrow and headed for the river'. Both clauses are independent, with 'In pain, Kukul pulled out the arrow' as the initiating clause and 'and headed for the river' as the continuing clause. The second is hypotaxis. It is represented in clause 'nexus and headed for the river to wash his wound' in which the clause' and headed for the river' as the dominant clause' and followed by clause to wash his wound' as the dependent clause.

\section{Logico-semantic Relation}

Gerrot and Wignell (1994, p. 89) statet that clauses can be joined through one of two logico-semantic relations: expansion/projection. Halliday (2004, pp. 376377) explain there is a wide range of different logico-semantic relations any of which may hold between a primary and a secondary member of a clause nexus. But it is possible to group these into a small number of general types, based on the two fundamental relationships of (1) expansion and (2) projection. 
(1) Expansion: the secondary clause expands the primary clause, by (a) elaborating it, (b) extending it or (c) enhancing it.

(2) Projection: the secondary clause is projected through the primary clause, which instates it as (a) a locution or (b) an idea.

The system network of taxis and logico-semantic relation can be seen in the diagram below (Gerot, L. \& P. Wignell , 1994, p. 93).

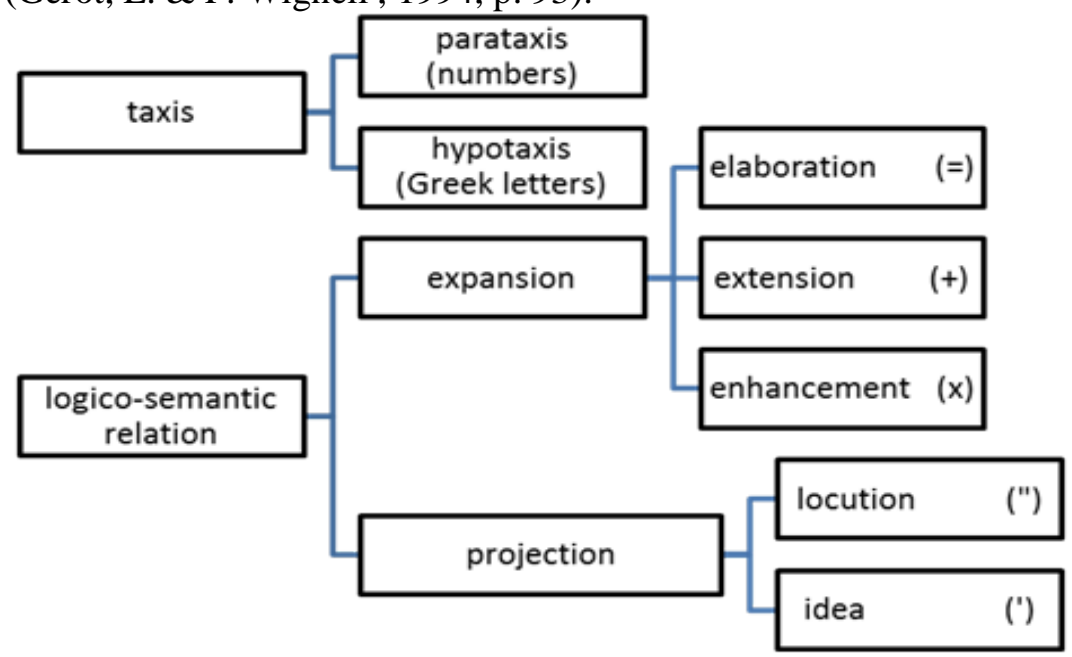

Diagram 1. The system network of taxis and logico-semantic relation

In relationships of expansion, Gerot and Wignell explained both the taxis and logico-semantic relationship can be identified through the marker which join the clauses, for example:

\begin{tabular}{|c|c|c|c|}
\hline Paratactic & $\begin{array}{l}\text { Elaborating } \\
\text { that is to say } \\
\text { or (rather) } \\
\text { in other words } \\
\text { for example } \\
\text { for instance } \\
\text { in fact, like }\end{array}$ & $\begin{array}{l}\text { Extending } \\
\text { and, but } \\
\text { not only } \\
\text { but also } \\
\text { Except } \\
\text { or, yet }\end{array}$ & $\begin{array}{l}\text { Enhancing } \\
\text { so, then } \\
\text { for, thus } \\
\text { or else } \\
\text { Still } \\
\text { Otherwise }\end{array}$ \\
\hline Hypotactic & Which & $\begin{array}{l}\text { Whereas } \\
\text { While } \\
\text { Instead } \\
\text { Besides } \\
\text { rather than }\end{array}$ & $\begin{array}{l}\text { as, while } \\
\text { when, where } \\
\text { Because } \\
\text { even though } \\
\text { Despite }\end{array}$ \\
\hline
\end{tabular}

\section{The Characteristic of Spoken Language}

Comparing spoken language with written language, Gerot and Wignell (1994, p. 158) argue that spoken language is typically more dependent on its context than written language is. In terms of grammatical intricacy, they also add that "in spoken language the content tends to be spread out over a number of clauses with complex logico-semantic relations among them". The amount of content words such as nouns, verbs, adjectives, and adverbs tends to be low in spoken language but the number of clauses per clause complex quite high. 


\section{Oral Presentation}

Oral presentation is one of speaking activities that is commonly used in English language learning context. It is defined as a method to show knowledge, give a lecture, be tested in a classroom, and build confidence to speak to an audience (Hall). Presentation is also defined as verbal report presented with illustrative material, such as slides, graphs (presentation). It is a kind of prepared talk, where a student (or students) makes a presentation on a topic of their own choices. Such talks are not designed for informal spontaneous conversation; because they are prepared, they are more 'writing like' than this. However, if possible, students should speak from notes rather than from a script (Harmer, 2008).

\section{Acceleration Program}

Acceleration program is one of the implementation of constitutional law National Educational System No.20 year 2003 article 5 verse 4, "bahwa warga Negara yang memiliki kercerdasan dan bakat istimewa berhak memperoleh pendidikan khusus”. Acceleration program is a program that particularly made for students who has gifted and talented (G\&T) potential. Acceleration program is different from regular program in terms of curriculum and time. In acceleration program, the education can be finished more quickly. It means the elementary students can be graduated after 5 years and for a high schooler after 2 years. SMA Labschool Jakarta is one of the institutions that contribute in serving and accommodating the gift and talented kid in the form of accelerated since 2000 until now.

\section{METHOD}

This study is a descriptive study. It helps researchers plan and carry out descriptive studies, designed to provide rich descriptive details about people, places and other phenomena (Hall). Therefore, the results are the description of the taxis and logico-semantic relation and the logical meanings of the clause complexes produced by the acceleration students of SMA Labschool Jakarta in their presentation.

The data sources are the final examination presentations in K-12 Acceleration Program of SMA Labschool Jakarta. The presentation slides are also used as data which indicate the ideas of the presentation.

Data collecting procedure are (1) The writer observed and recorded the oral presentations of acceleration students. (2) The recording was listened and transcribed into Latin symbols. The slides in the powerpoint was also retyped which can be considered as the beginning ideas of presentation. (3) After transcribing the recordings, the writer put the data into table in which the coloumn consist of number, points in slides, and the clause complexes. The analysis then is done in students' utterances one by one.

Data Analysis Techniques: the instruments used to analyze the data are the theories of the clause complex system of interdependency, the logico-semantic relation and the meanings of the clause complexes. Consequently the units of analysis are clause complex and clauses. Here, the focus of the study is nonembedded clauses. Gerot and Wignel defines non-embedded clause as a dependent 
clause, one which adds a kind of afterthought. Each of the data is firstly identified its clause complexes, then analyzed their system of interdependency and logicosemantic relation, and the logical meanings of the clause complexes.

When analysing clause complexes there are some steps proposed by Gerot and Wignell (1994, p. 96):

- List each clause vertically down the page, lettering each clause complex (A,B,C, etc) and numbering each clause in the clause complex (i, ii, iii, etc.)

- Display analysis on left-hand side of text

- Begin a new layer (indent) whenever there is a change in taxis or a change in logico-semantic relation. So, for example using these guidelines, step by step the clause complexes below are analysed as follows:

(A) (i) $\alpha \quad$ Each level of government has its set duties

(ii) $=\beta \quad$ which it must carry out

(B) (i) $1 \alpha$ She never enjoys parties

(ii) $\mathrm{x} \beta$ if her boyfriend's not there

(iii) $\mathrm{x} 2$ so we didn't invite her

After finishing the analysis of taxis and logico-semantic relation of the students' presentation, the writer decided the meanings represented in each relation. In determining the meaning, the writer used the concept of relationship between clauses proposed by Halliday.

\section{RESULTS AND DISCUSSION}

\section{The Clause Complex 1}

The idea of the clause complex 1 is "Why Bullying?”. The relations which arise in this clause complex are hypotactic enhancement, 2 paratactic elaboration, and 4 paratactic extension. The hypotactic enhancement is used in case they stated the reason they chose bullying as their topic. It can be illustrated in the following sample.

"And why we chose bullying of more than 14 million other social problems in this world, First, it's happening anywhere, anytime, and to anyone, it's closest to teenagers, it's destructive as poppies, but it is ignored like daisies and the fact is teenagers involved in bullying increase by $17 \%$ and it's still increasing”

Table 2. Type of Taxis and Logico-Semantic Relation and Category.

\begin{tabular}{cll}
\hline No. & Types of taxis and logico-semantic relation & Meaning/Category \\
\hline 1. & Hypotactic enhancement & Cause-reason \\
\hline 2. & Paratactic elaboration & Clarification \\
\hline 3. & Paratactic elaboration & Exemplification \\
\hline 4. & Paratactic extension & Additive \\
\hline 5. & Paratactic extension & Adversative \\
\hline 6. & Paratactic extension & Adversative \\
\hline 7. & Paratactic extension & Additive \\
\hline
\end{tabular}

\section{The Clause Complex 2}

The idea of the second clause complex is "What is Bullying?”. In the clause complex, there are nexuses; paratactic idea, paratactic extension, and paratactic locution. Here, the student gave definitions of bullying. Paratactic idea appears when 
student give a definition from Oxford English Dictionary, while paratatic idea occurs when she quotes definition of bullying from expert. The clauses of paratactic locution.

And expert says bullying is a system of power abuse where the bully repeatedly uses his or her power to intimidate or to harm the victim both physically and psychologically.

Paratactic extension is used when the student moved from one definition to another to give a new information. The clause complex produced here matches the points in the slide.

Table 3. Type of Taxis and Logico-Semantic Relation and Category.

\begin{tabular}{cll}
\hline No. & Types of taxis and logico-semantic relation & Meaning/Category \\
\hline 1. & Paratactic idea & Proposition \\
\hline 2. & Paratactic extension & Addition \\
\hline 3. & Paratactic locution & Proposition \\
\hline
\end{tabular}

\section{The Clause Complex 3}

The idea of the clause complex is concluding the definition. There are 12 relations which cover 2 hypotactic enhancement, 4 paratactic elaboration, 4 paratactic extension, and 2 paratactic enhancement. In the slide the student provided points that would describe bullying; intimidation/injuring, mentally/physically, repetitive, rudeness toward the people $>$ bullying. The word intimidation or injuring is considered as the main definition of bullying, then it is reinforced with another clause, and is also exemplified. Those are the meanings of elaboration. The clauses are like the following :

bullying is intimidation or injuring so you can intimidate like hit a person or kick or injured them like that or intimidating like calling the names mocking them like that

The student makes use of paratactic elaboration to add the description of bullying. It is realized through such clause like and it's both mentally and physically. Overall, what is said by the student is relevant with the points in slide.

Table 4. Type of Taxis and Logico-Semantic Relation and Category.

\begin{tabular}{cll}
\hline No. & Types of taxis and logico-semantic relation & Meaning/Category \\
\hline 1. & Hypotactic enhancement & Cause: purpose \\
\hline 2. & Hypotactic enhancement & Cause: condition \\
\hline 3. & Paratactic elaboration & Exemplification \\
\hline 4. & Paratactic elaboration & Exemplification \\
\hline 5. & Paratactic elaboration & Exposition \\
\hline 6. & Paratactic elaboration & Exposition \\
\hline 7. & Paratactic extension & Alternation \\
\hline 8. & Paratactic extension & Addition \\
\hline 9. & Paratactic extension & Addition \\
\hline 10. & Paratactic extension & Addition \\
\hline 11. & Paratactic enhancement & Cause: reason \\
\hline 12. & Paratactic enhancement & Cause: reason \\
\hline
\end{tabular}




\section{Clause Complex 4}

The idea of the clause complex is the type of bullying. The types are classified in some characteristics; general type, according to places occured and instruments. In the analysis, the writer divides the analysis based on the characteristics. The clause nexuses produced when the student explained the general type of bullying consist of various relations; 7 paratactic elaboration, 2 hypotactic idea, 3 paratactic extension, 2 hypotactic enhancement, and 3 hypotactic locution. The meanings that the student used are clarification, in which she clarified the the types of physical, verbal, and psychological, or exemplified them such as in these clauses.

I will present about the types of bullying, The general type which is...which are physical, verbal, and psychological

In physical bullying ... ehm we know that people ... ehm who ... each other physically, They hit each other, they ... ehm not hit each other, I mean ...ehm the bullies hit the bullied

Table 5. Type of Taxis and Logico-Semantic Relation and Category.

\begin{tabular}{cll}
\hline No. & Types of taxis and logico-semantic relation & Meaning/Category \\
\hline 1. & Paratactic elaboration & Clarification \\
\hline 2. & Paratactic elaboration & Clarification \\
\hline 3. & Paratactic elaboration & Exemplification \\
\hline 4. & Paratactic elaboration & Exemplification \\
\hline 5. & Paratactic elaboration & Exemplification \\
\hline 6. & Paratactic elaboration & Clarification \\
\hline 7. & Paratactic elaboration & Exemplification \\
\hline 8. & Hypotactic idea & Proposition \\
\hline 9. & Hypotactic idea & Proposition \\
\hline 10. & Paratactic extension & Addition \\
\hline 11. & Paratactic extension & Addition \\
\hline 12. & Paratactic extension & Addition \\
\hline 13. & Hypotactic enhancement & Conditional \\
\hline 14. & Hypotactic enhancement & Cause: reason \\
\hline 15. & Hypotactic locution & Proposal \\
\hline 16. & Hypotactic locution & Proposition \\
\hline 17. & Hypotactic locution & Proposition \\
\hline
\end{tabular}

When explaining the types of bullying according to places occured, the student produces only one relation which is paratactic extension and the meaning is adversative.

And according of the places occurred, there will be school, workplace, and internet But we only talk about the ones in the school.

In this section the student did not elaborate the type. In the next explanation, the student stated about the types of bullying based in the instrument. The number of relation produced is 4 consisting 2 paratactic elaboration and 2 paratactic extension. In relation of paratactic elaboration, the student made use of clarification and exemplification. These can be seen through this clauses.

(i) 1 And the instruments ehm I mean the media and the influences are the internet and direct bullying 
(ii) $=2 \quad 1 \quad$ In internet $\ldots$. ehm people do cyber bullying

(iii) $=2 \quad$ like . . . ehm you can see in the picture here "I can bring your life no one likes you looser" like that

Table 6. Type of Taxis and Logico-Semantic Relation and Category.

\begin{tabular}{cll}
\hline No. & Types of taxis and logico-semantic relation & Meaning/Category \\
\hline 1. & Paratactic elaboration & Clarification \\
\hline 2. & Paratactic elaboration & Exemplification \\
\hline 3. & Paratactic extension & Addition \\
\hline 4. & Paratactic extension & Addition \\
\hline
\end{tabular}

\section{Clause Complex 5}

The idea of this clause complex is the characteristics of the Bully, the Bystanders, and the Bullied. The relations found are 4 paratactic elaboration, 3 hypotactic enhancement, 3 paratactic locution, 1 hypotactic elaboration, and 1 paratactic extension.

Paratactic elaboration in the clause complex has clarification and exemplification meaning, like in the following clauses

(i) 1 The characteristics, the bully is usually selfish ehm

(ii) $=2$ they're full of power

(iii) 1 Sometimes we are . . they are afraid of the bully,

(iv) $\quad=2$ so, like they act as neutral

(v) = 3 so, they .. they don't get into the fights,

(vi) = 4 And they only .. they only like "oh that's not my problem"

Hypotactic enhancement found here has meaning of cause:result and temporal. These are the clauses.

(ii) $\quad \alpha \quad$ they're full of power

(iii) $\quad \mathrm{x} \beta$ because maybe ...ehm their looks are bigger than the bullied

(i) $\quad \alpha \quad$ They're usually . . . like their body posture . . . they look down

(ii) $\quad \mathrm{x} \beta \quad$ everytime they walk

The example of paratactic locution.

(vii) 1 When people said

(viii) “ 2 "you're the bully”,

Table 7. Type of Taxis and Logico-Semantic Relation and Category

\begin{tabular}{cll}
\hline No. & Types of taxis and logico-semantic relation & Meaning/Category \\
\hline 1. & Paratactic elaboration & Clarification \\
\hline 2. & Paratactic elaboration & Clarification \\
\hline 3. & Paratactic elaboration & Exemplification \\
\hline 4. & Paratactic elaboration & Exemplification \\
\hline 5. & Hypotactic enhancement & Cause: result \\
\hline 6. & Hypotactic enhancement & Cause: result \\
\hline 7. & Hypotactic enhancement & Temporal \\
\hline 8. & Paratactic locution & Proposition \\
\hline 9. & Paratactic locution & Proposition \\
\hline
\end{tabular}




\begin{tabular}{lll}
\hline 10. & Paratactic locution & Proposition \\
\hline 11. & Hypotactic elaboration & Description \\
\hline 12. & Paratactic extension & Addition \\
\hline
\end{tabular}

\section{The Total Result}

Results of the analysis reveal that the acceleration students produce various kinds of taxis and logico-semantic relation in their presentation. They make use of the taxis and logico-semantic relation to communicate the idea of their presentation. Likewise, the meanings represented by the clause complexes they produce are as varied as the the kinds of taxis and logico-semantic relation. Below are the detail result of the analysis.

\section{The Distribution of Kinds of Taxis and Logico-Semantic Relation in the First Group Presentation.}

The first group consists of 4 female students and talks about Bullying. The result analysis of the first group reveals that there are 169 clause nexus produced by the students with various kinds of relations. The distribution of the kinds of relations can be seen in the table below.

Table 8. The number of kinds of taxis and logico-semantic relation in the first group.

\begin{tabular}{clc}
\hline No. & The kinds of taxis and logico-semantic relation & $\begin{array}{c}\text { Number in the } \\
\text { presentation }\end{array}$ \\
\hline 1. & Paratactic Elaboration & 58 \\
\hline 2. & Hypotactic Elaboration & 7 \\
\hline 3. & Paratactic Extension & 34 \\
\hline 4. & Hypotactic Extension & 0 \\
\hline 5. & Paratactic Enhancement & 10 \\
\hline 6. & Hypotactic Enhancement & 37 \\
\hline 7. & Paratactic Locution & 7 \\
\hline 8. & Hypotactic Locution & 4 \\
\hline 9. & Paratactic Idea & 5 \\
\hline 10. & Hypotactic Idea & 7 \\
\hline Total & & 169 \\
\hline
\end{tabular}

\section{Kinds of Taxis and Logico-Semantic Relation}

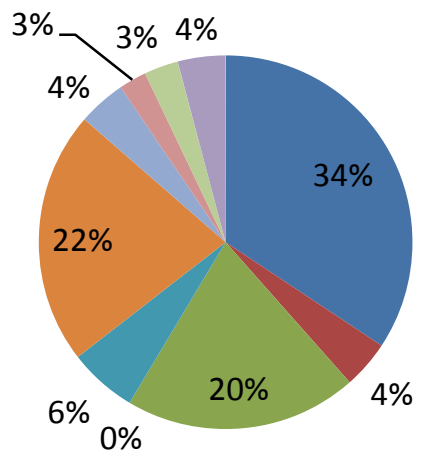

Paratactic Elaboration

- Hypotactic Elaboration

Paratactic Extension

Hypotactic Extension

Figure 1. Kinds of Taxis and Logico-Semantic Relation 
From the table above, it can be seen that the students of the first group almost make use of all relationship except hypotactic extension. The kind of taxis and logico-sematic relation which most arises is paratactic elaboration that accounts for 58 clause nexus from 169 clauses.

\section{The Distribution of Kinds of Taxis and Logico-Semantic Relation in the Second Group}

The second group consists of 4 male students who were presenting about Save the Energy: Transportation. The number of clause nexuses produced is 68. It is fewer than the first group. However, the kinds of taxis and logico-semantic relation in their presentation are also various. The following table shows the distribution of the relation.

Table 9. The number of kinds of taxis and logico-semantic relation in the second group.

\begin{tabular}{clc}
\hline No. & The kinds of taxis and logico-semantic relation & Number in the presentation \\
\hline 1. & Paratactic Elaboration & 18 \\
\hline 2. & Hypotactic Elaboration & 10 \\
\hline 3. & Paratactic Extension & 13 \\
\hline 4. & Hypotactic Extension & 3 \\
\hline 5. & Paratactic Enhancement & 6 \\
\hline 6. & Hypotactic Enhancement & 16 \\
\hline 7. & Paratactic Locution & 0 \\
\hline 8. & Hypotactic Locution & 0 \\
\hline 9. & Paratactic Idea & 1 \\
\hline 10. & Hypotactic Idea & 1 \\
\hline Total & & 68 \\
\hline
\end{tabular}

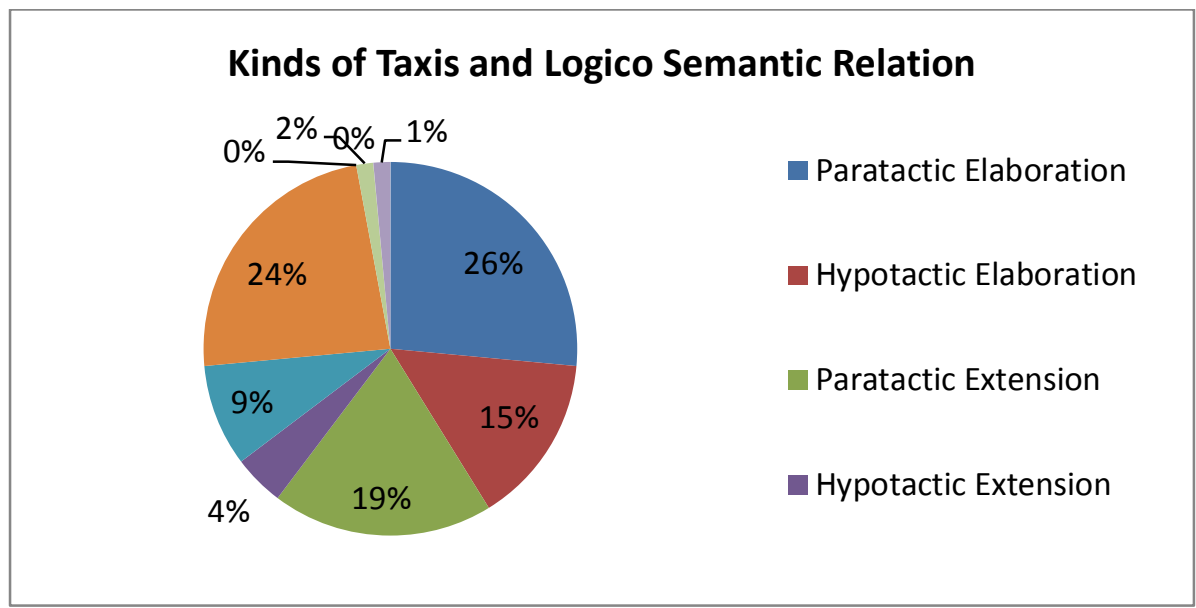

Figure 2. Kinds of Taxis and Logico-Semantic Relation

\section{The Meanings Represented by Clause Complexes}

In each kind of taxis and logico-semantic relation, there will be meaning which is carried out through the realization of clauses. As already stated in the literature review, every kind of relation has its own meaning. The following section will be an explanation of meanings produced in the acceleration students. 


\section{The Meanings Represented by Clause Complexes of the First Group Presentation}

In the elaboration relationship, the students make use of all meanings. In paratactic elaboration, the meanings are 8 exposition, 20 exemplification and 32 clarification, while in hypotactic elaboration, there are 5 description. From 34 extension, there are 33 addition and 1 alternation. Then in the enhancement, the category of meanings founded are 30 cause-reason type, 7 conditional type, 2 causeresult type, 2 concession, 2 temporal and 2 manner. In locution, there are 8 proposition, and 3 proposal, while in relation of idea there are 10 proposition and 3 proposal.

\section{The Meanings Represented by Clause Complexes of the Second Group Presentation}

In the elaboration relationship, the students make use of all meanings. In paratactic elaboration, the meanings are 3 exposition, 8 exemplification and 7 clarification, while in hypotactic elaboration, there are 10 description. From 16 extension, there are 15 addition and 1 alternation. Then in the enhancement, the category of meanings founded are 8 cause-reason type, 3 conditional type, 4 causepurpose type, 1 concession, and 6 manner. In idea, there are 1 proposition, and 1 proposal. In the presentation of the second group, there is no locution that they produce.

\section{CONCLUSION}

The analysis of taxis and logico-semantic reveals that the students of acceleration program have a good complexity in the production of their language. The analysis result of taxis reveals that the girl students have produced 169 clause nexus, while the boy students produce 68 clause nexus. The dominance of type of taxis in girl students is parataxis which reaches $68.05 \%$, and the rest is hypotaxis. In boy students' presentation, they produce $55.88 \%$ parataxis and 44 , $2 \%$ hypotaxis. The dominant type of logico-semantic relation in girl's presentation is elaboration. The same thing occur in boy's presentation, the dominant type of the logico-semantic relation produced is elaboration. In terms of meaning, the girl students make use of various meanings, and also the boy students. In elaboration for example they use clarification, exemplification, exposition and description.

The variation types of taxis, logico-semantic relation and meanings produced by the acceleration students prove the strength of their verbal language. Despite the young age they are, they have language ability that may be higher than other students in the same age.

Referring to the conclusions of the finding, the recommendation are offered as the following: (1) The teacher of the accceleration students need to develop their teaching strategies so that the students' language ability can develop as well. (2) The study of clause complexes, particularly taxis and logico-semantic relation system need to be learned more deeply. (3) The English Department students may learn the way how to present in appropriate way. 


\section{REFERENCES}

Gerot, L. \& P. Wignell . (1994). Making Sense of Functional Grammar. Sydney: Gerd Stabler.

Hall, S. (n.d.). The Descriptive Method of Research Design. Retrieved June 12, 2012, from eHow.com: http://www.ehow.com/

Halliday, M. .. (2004). An Introduction to Functional Grammar (3rd Edition ed.). (C. M. Matthiessen, Ed.) London: Edward Arnold.

Harmer, J. (2008). The Practice of English Language Teaching. Longman ELT.

Moore, K. D. (2005). Effective Instructional Strategies: From Theory to Practice. London: Sage Publication, Ltd.

Presentation. (n.d.). Collins English Dictionary - Complete \& Unabridged 10th Edition. Retrieved June 20, 2012, from Dictionary.com: http://dictionary.reference.com/browse/presentation

Rukmini, D. (2010, Desember). jurnal.umk.ac.id. Retrieved May 27, 2012, from http://jurnal.umk.ac.id/jurnal/

Saragih, A. (2008). Introducing Systemic Functional Grammar. Medan: English Department Faculty of Languages and Arts the State University of Medan. 
International Journal of Language Education and Culture Review 